\title{
Documentary Radio and the Radical Origins of Public History
}

\section{Rachel Donaldson}

Public history in the United States is a widely defined field with several professions, shaped by various academic disciplines falling under its purview. At its core, public history encompasses historians working outside of the academy, creating historical works directed to a general rather than scholarly audience. While this articulation of the field is applicable to a long history of historical endeavours in curating, material preservation, and cultural conservation dating back centuries, public history as a self-reflective profession with a core methodology guided by a defined set of best practices is a much more recent development. The traditional narrative traces the beginning of formal training in public history back to the dearth of academic jobs in the 1970s, which pushed history PhDs to seek work outside of the academy. According to the founding editor of The Public Historian, G. Wesley Johnson, this education focused on teaching the kinds of skills "that could be used for public benefit, whether in business, government, foundations, historical societies," and the like. ${ }^{1}$ While the practical side of this origin story focuses on how historians forged non-academic paths in the public realm, the social and political side emphasizes that the field began as a movement. Formed in the crucible of 1960s and 1970s student activism of the New Left, the public history movement was also shaped by the intellectual social turn in which the "people's history" of underrepresented groups, as well as local history, became a focus of academic discourse among historians. $^{2}$ By the 1980 s, many public historians began working with marginalized communities to preserve, interpret, and present their histories in the public realm, an approach that marked a sharp departure from the earlier public-facing history efforts of museum curators, historic preservationists, decorative arts conservators, and folksong collectors, which focused primarily on the tangible and intangible artifacts of historical elites.

The historiography of public history has largely been written by those who participated in the field's genesis, which is problematic. In the past few decades, public history practitioners and scholars have generated new works that examine the longer historical trajectory of the field and the roots of different professions that fall under its wide umbrella. ${ }^{3}$ Like the recent scholarship of the field, this article disrupts the accepted origin narrative by examining the historical, social and political underpinnings of public history. I do not dispute the claim that the movement side of public history is constructed from a foundation grounded in progressive politics-this explains the field's current emphases on enhancing democratic institutions, promoting social inclusion in historical commemoration, and advocating social justice-rather, I question when and where this foundation was established 
and, thus, what perspectives shaped it. Tracing the establishment of public history as a self-reflective profession back further than its presumed emergence in the $1960 \mathrm{~s}$ and 70 s not only provides a more nuanced history of public history, but also complicates the larger historical understanding of the eras in which both emerging and established public historians have operated.

History in the public realm is not unique to the twentieth century. Key professions that intersect with public history, including museum curating, archival management, and historic preservation, all emerged largely in the nineteenth century and evolved over the course of the twentieth. Many of the early figures in these areas were either antiquarians who focused on conserving aspects of the pastlargely to save them for their own sake or to impart the values of past elites on the rapidly growing immigrant and working-class urban communities_-or academics who sought to conserve remnants of the past that were threatened by the forces of modernity; in many respects, these two groups overlapped. ${ }^{4}$

Although public historians have had a close relationship with academic historians, and often receive formal historical training, they were - and are - not bound to the academy. Their focus on communicating and working with the public ties them much more closely to the larger political and social context of their eras; their work reflects the reciprocal relationships they maintain with public audiences across varying political climates. Historical studies of public history therefore shed important light on the development of the field itself and the social and political history of the places where it developed-in the case of this study, the United States.

A watershed moment in the history of public history occurred during the Depression era, when public-facing historians and history enthusiasts morphed from ad hoc groups of antiquarians to professionals in fields that would connect with public history, such as archives, historic preservation, public folklore, oral history, and documentary production. This took place largely because of an influx of federal money and support for public-facing historical initiatives that enhanced New Deal programs. ${ }^{5}$ The passage of the 1935 National Historic Sites Act proved foundational for the rise of federal historic preservation; the Society of American Archivists began to forge its own path apart from the American Historical Association in 1936; Pare Lorentz's sweeping documentaries informed the public of soil conservation programs and rural electrification projects by educating viewers on the historical basis for such initiatives; and public-facing folklorists preserved and disseminated examples of cultural heritage and nascent oral histories through government agencies such as the Archive of American Folk Song (AAFS), the music division of the Farm Securities Administration, and the Federal Writers Project.

Much of the work that these historians and history-adjacent professionals engaged in focused on protecting the cultural traditions of struggling Americans, as well as highlighting their contemporary conditions. At the same time, political activists engaged in efforts to change these conditions-organizing displaced tenant 
farmers and unemployed urban workers, advocating federal anti-lynching legislation, and fighting the racist ideology of fascism. Many public-facing historians sympathized with these efforts and incorporated these views into their own work. Using historical themes and armed with historical evidence, these early public historians taught the American public to embrace civic ideals such as economic and social justice as well as political and cultural democracy-ideas that continue to shape contemporary public history in the twenty-first century. One program that epitomized the intersection of public-facing historical work and a version of social justice advocacy in the late 1930s and early 1940s was the Radio Research Project (RRP) of the Library of Congress.

Funded by the Library and a special grant from the Rockefeller Foundation, the RRP consisted of a series of educational radio shows designed to introduce the listening public both to the holdings of the Library and to other Americans living in regions across the country. More importantly, RRP officials designed these broadcasts to help in the ideological battle against the spread of fascism by securing listeners' commitment to democratic civic ideals. ${ }^{6}$ Program directors, technicians, and writers ranging from progressive liberals like Archibald MacLeish, Jerry Weisner, and Philip Cohen, to leftists including Alan Lomax, Benjamin Botkin, and playwright Arthur Miller, imbued the project with language reflecting the type of antifascist rhetoric common in progressive circles of the era. Understanding the RRP as a form of nascent public history restructures the understanding of the political foundation of the field, for, rather than emerging from the activism and ideology of the New Left, it actually began during the era of the Popular Front-shaped by the politics of left-wing Americanism and New Deal populism. ${ }^{7}$

Through its various scripted programs that largely focused on historical themes, the RRP played a significant role in the development of historical approaches that would come to form the core of public history: an emphasis on grassroots perspectives of marginalized communities, a focus on local history, and an effort to ensure that different groups of Americans would see themselves represented in depictions of the national collective past. Many of the key figures in the RRP were applied folklorists (folklorists who directed their projects to a public rather than academic audience) who worked in the Library's Archive of American Folksong. Even though they were not historians, they used folk materials as historical resources in their programs. The applied folklorists in the RRP moulded the project in still more ways that would reappear in early public history programs: they generated historical interpretations that relied on a variety of approaches and perspectives from academic fields beyond history; they emphasized a strong connectedness with the past by illustrating the ways in which the past continued to inform the present; and, perhaps most importantly, they generated opportunities for the people to speak for themselves directly to listeners, rather than relying exclusively on scripted narration. Significantly, these figures crafted their historical programs outside of the academy, taking their interpretations directly to the American people 
over radio airwaves. Situated at the nexus of emerging public history and public folklore, the RRP illustrates how intertwined the two fields are, as well as their mutual political underpinnings. ${ }^{8}$

With its debut in January 1941, and termination in early 1942, the RRP also provides important insight into two aspects of American history during this period. First, it illustrates the continued pro-democracy and antifascist efforts among American leftists that had characterized the programs of the Popular Front during its official hiatus (1939-1941), thus complicating the historical understanding of how the Popular Front operated in the American context. Second, it provides an important example of the ways in which cultural and political figures used radio to spread the kind of civic ideals that would come to characterize wartime propaganda, which adds an important dimension to the history of American radio at its zenith.

\section{Origins and Ideology}

In June 1939, Franklin Roosevelt appointed the poet Archibald MacLeish to replace outgoing Librarian of Congress Herbert Putnam - much to the consternation of American Library Association members who protested his complete lack of administrative experience. Conservatives also balked at the appointment, claiming that MacLeish, who had written favourably about New Deal Programs, was a Communist sympathizer, but Congress approved his appointment on July 29 after a brief five-minute interview. ${ }^{9}$ MacLeish, like most New Deal liberals and all American leftists, was strongly antifascist — a position that hardened after the fall of the Spanish Republican Government and Germany's invasion of Poland in 1939.

Antifascism had also been the main tenet of the Communist Popular Front. While the RRP was housed in the Library of Congress and supported by federal funds, the views expressed in the programs tilted strongly toward the Left, particularly in their explicit antifascism. The injection of left-wing views into mainstream radio discourse was possible because of the nature of the Popular Front and how it developed in the United States. ${ }^{10}$ In the summer of 1935 , the central report delivered at the Seventh Congress of the Communist International announced a sharp turn from the Third Period's emphasis on revolution, in which Socialists and Social Democrats were viewed as enablers of fascist regimes. Now, the Comintern called for a "People's Front" that would unite Communists with progressives who were also resisting fascism. In the United States, American Communists joined forces with New Deal liberals, mainstream labour unions, socialists, and other radicals in the struggle against fascism. While Party leaders like Earl Browder and William Z. Foster had to adjust to this realignment of Party goals, according to historian James Barrett, the rank-and-file embraced it, leading what would become a Communist "movement." Moreover, while the collaborative emphasis of the Popular Front marked a departure from the isolationism of the Third Period, the mandate gave credence to the types of cooperative activity in which many Communists had already been engaged, even without Party sanction. The crisis of the Depression 
not only helped to galvanize the labour movement, it also prompted more radical forms of organizing, especially among unskilled workers. Their actions in unemployed and industrial union movements, in turn, led to what Michael Denning refers to as the "laboring" of American culture, which was reflected in literary, artistic, theatrical, musical, film, and other cultural products that highlighted themes of social and economic justice, promoted democratic reforms, and celebrated the downtrodden. Therefore, the practice of cooperation that became the theoretical core of the Popular Front was "produced not by Comintern fiat alone, but rather by the exigencies of revolutionary practice in a wide range of places, including the cities of the United States."11

In attempting to more fully understand the complexities of the Popular Front, historians need to look more closely at the rank-and-file members who formed the movement, rather than focusing on the Party infrastructure and leadership. The highly centralized and "fundamentally undemocratic" Party did not change during this period in terms of structure and organization, but the culture surrounding it did, spurred by the new members of the rank-and-file. ${ }^{12}$ During the Third Period, Communist Party (CPUSA) membership largely consisted of foreign-born males in a smattering of urban locales. By the late Popular Front era, membership had grown to encompass a younger cohort of native-born men and women across the country. The Americanizing of the CPUSA was apparent at the 1939 convention, where 80 percent were native-born citizens. ${ }^{13}$ Much of this generation was galvanized by antifascism rather a faithful devotion to Party politics. This general left-wing zeitgeist therefore blurred the lines between "Communist" and "leftist" during the late 1930s. Yet, at the same time, when the Comintern halted the Popular Front by fiat in 1939 and no longer supported Front-related activities, much of the rank-and-file followed the Party line. Fellow travellers, however, left en masse, and some, including Congress of Industrial Organizations (CIO) unions and the American Civil Liberties Union (ACLU), began to oust Communists from their ranks. ${ }^{14}$

What happened to the Communist movement when the Party effectively closed ranks? In many ways the work that rank-and-file Communists had done did not necessarily stop with the Popular Front termination. In response to Barrett, Michael Denning flips the script of Popular Front historiography, arguing that the history of the Popular Front does not relate solely to the history of the Party, but "rather, the history of the Communist Party is a subset of the history of the Popular Front social movement, one of the most important and influential social movements in U.S. history." ${ }^{15}$ During this period, Popular Front organizers worked to create a "Popular Front civic culture" that united working-class industrial labourers with middle-class white-collar workers; they sought to form ethnic and racial alliances that would lead to an "Americanism" that included immigrant and African American workers' culture and incorporated them into the national identity. In this effort they adopted three main platforms: anti-fascism, anti-imperialism, and antilabour repression and lynching. ${ }^{16}$ Many activists sustained these views even after 
the Nazi-Soviet Pact, and examining their actions in the period between the end of the Popular Front in 1939 and its revival in 1941-particularly in the case of programs that dealt with America's relationship to the war overseas and the looming spectre of US involvement in another world war-illustrates the depth and breadth of this movement.

The advance of fascist forces in Europe prompted many leftists and liberals to work together in amassing an ideological arsenal of pro-democracy propaganda to gird against the spread of fascist ideas on US soil. In 1939, the American Library Association commissioned two bibliographies titled "The Dangers to Democracy"; by 1940, the Librarian of Congress initiated his own drive to bring the American intelligentsia into the fight against fascism, writing,

We face a situation which has an "either" and which has an "or" and we will choose or fail to choose between them ... The "either" as I see it is the education of the people of this country. The "or" is fascism. We will either educate the people of this republic to know and therefore to value and therefore to preserve their own democratic culture or we will watch the people of this republic trade their democratic culture for ... the brutality, the tyranny which is overrunning eastern and central and southern Europe. ${ }^{17}$

MacLeish believed that the best way to achieve the "either" was by teaching the American public the value of democracy-and that democracy was the cornerstone of their political heritage - through popular educational programming, with libraries being most suitable for the task. Fortunately for MacLeish, John Marshall, the assistant director of the Rockefeller Foundation's Humanities Division, agreed. While he too supported the idea of a democratic propaganda campaign, he recognized that if it were rooted in education, such a program would differ from the commercial or political wartime propaganda of the past. ${ }^{18}$ Thus, the RRP formed from these circumstances, and the kind of education it emphasized was historical in nature: teaching Americans about their democratic heritage in ways that intentionally connected their past to their present.

With Philip H. Cohen as chief, Charles T. Harrell as program editor, Joseph Liss as script editor, and Alan Lomax as the music and folklore editor, the RRP aimed to explore how the medium of radio could introduce Americans to the "record of American culture" contained in the Library. By weaving together excerpts of local and national materials housed at the Library, the project leaders endeavoured not simply to teach listeners about their collective past, but also to educate them on national civic values. Another purpose of the project was to promote national unity by encouraging the American listening public to think of their fellow citizens as neighbours- presenting the various dialects, struggles, and quo- 
tidian experiences of those living in geographically disparate communities. ${ }^{19}$

The idea of creating radio programs to shape public opinion was not new. While commercial networks were initially squeamish about educational programming, they eventually fell in line in the early 1930s, with CBS's American School of the Air being one example. In 1935, NBC began airing America's Town Meeting of the Air, produced by the League for Political Education. Designed as a public forum program intended to evoke early New England town hall meetings, the show featured debates among public intellectuals about contemporary issues before a live studio audience. ${ }^{20}$ The US Office of Education even engaged in efforts to encourage Americans to embrace such civic ideals as cultural pluralism and political democracy through educational shows such as Americans All...Immigrants All (1939) that celebrated the contributions that ethnic and racial groups made to American life. The RRP, however, was one of the first educational programs to teach Americans civic values by adopting a form that would come to shape the modern concept of documentary. Historian Michele Hilmes uses the phrase "public service documentary drama" to refer to

original works written especially for radio, mixing drama and documentary in creative ways, with a frequent emphasis on the idea of nation and national identity-history, issues and problems, concepts such as democracy and freedom — and an underlying aesthetic of factuality, even when scripted and performed by actors.

While this concept emerged from radio programming on the BBC, it applies almost directly to the RRP programs. ${ }^{21}$ Furthermore, in many of the shows, particularly those that incorporated folklore, the people who presented songs and stories to the listening audience were tradition-bearers rather than actors performing scripted pieces, which was an approach that had not been heard on American radio before. ${ }^{22}$

The timing of the RRP was apt, for NBC and CBS, the two major radio networks, had open time slots for non-commercial radio shows, and by this time network officials had become especially interested in educational programs. By the late 1930s, educational radio had established a strong presence and received significant financial support from private foundations, notably the Rockefeller Foundation. ${ }^{23}$ This worked out well because MacLeish realized that the RRP programs had to be aired over these networks if they were going to reach the masses. ${ }^{24}$

Of all forms of mass media, radio was the one that could reach the widest audience possible for the ideas expressed in RRP programs. The decade of the 1930s marked the highpoint for American network radio, for it was then that radio truly amassed a mass audience. Not only did the commercial dominance of radio solidify during this decade with the Communications Act of 1934, but radio also became regionally centralized, with networks in New York controlling 93 percent 
of the country's "broadcasting power" by $1937 .{ }^{25}$ Even local stations played shows distributed by the two radio monoliths, NBC and CBS, which contributed to the creation of a national culture over the airwaves. During this period, radio was viewed as the medium to connect to the American public, which had profound implications for how leaders, pundits, and cultural critics interpreted its power. ${ }^{26}$ Radio's ability to reach a vast audience led civic-minded artists to turn to the medium as a way to reach out to Americans with art that addressed contemporary political and social issues. The program Columbia Workshop on CBS was one such example, and Archibald MacLeish was a key participant on this program. ${ }^{27}$ Near the close of the 1930s, as war loomed on the horizon in Europe, federal officials turned to radio in an attempt to create and spread a more inclusive interpretation of the American past that included the perspectives of marginalized groups, including African Americans, immigrants, and Jews. This was driven by the recognition of the very real possibility of America becoming involved in another world war, should one break out, and of the country needing some degree of social unity in that event. ${ }^{28}$

Although broadcast radio could disseminate civic educational programs among a diffuse public, it still was an almost entirely commercial enterprise, controlled by corporate interests. Artists and commentators that tried to use it as a civic space for critical public art and engagement therefore had to contend with the business interests controlling the airwaves. ${ }^{29}$ In fact, part of the justification for the RRP stemmed from certain qualms about the commercial nature of American radio. Project directors argued that network radio stations were creating a conformist mass culture based solely in urban centres. They argued that by producing programs showcasing diverse regions and featuring ordinary citizens, they could combat this process by enhancing the representation of local and regional voices, even though the project leaders were a centralized group under the wing of the federal government. The RRP's consistent emphasis on illustrating American cultural, social, racial, and ethnic diversity fell closely in line with the cultural pluralist ethos of Popular Front Americanism. Furthermore, after the outbreak of the Second World War, RRP leaders wanted their work to have social significance and to aid in a struggle that they viewed in terms of a democratic Allied effort against the racial nationalism and imperialism of the Axis powers. ${ }^{30}$

Of all the civic ideals supposedly embedded in the American Creed, the one that each program of the RRP emphasized was democracy, exploring how democratic themes played out across the country. One of the key programs that reinforced this message, almost ad nauseam, was the Regional Series. This program consisted of different scripted episodes that detailed the histories of particular towns and regions across the country. While each one focused on the particular circumstances of local history, their purpose was to illustrate the regional manifestations of national principles. Project officials described the purpose of the Regional Series as introducing Americans to each other while also reinforcing their civic faith in democratic ideals, and explained that the series 
would acquaint the people of this country with their neighbors who are far away and about whose customs, traditions and problems they know very little, and it would help to bring about real unity as opposed to the talked about unity that now exists. In this program the people of America will show democracy in action rather than democracy dramatized. ${ }^{31}$

Specifically, the project leaders sought to show how all facets of life in these communities either "contribute[d] to democracy" or, conversely, impeded democracy and thus "may lead to the establishment of undemocratic procedures and influences." 32 Program writers were instructed to show that democracy is both a continuing process and something that needs to be actively pursued, and that if people do not consistently work to reinforce it, democracy could be destroyed by fascist forces.

Exploring national themes through local histories could be difficult, and project leaders were mindful to make the histories they presented relatable to a diverse listening audience. MacLeish, for one, wanted to ensure that the episodes did not fall into the trap of regional romanticism, cautioning writers to "avoid at all costs an anthology of quaint customs, curious history and antiquarian charm." Writers were instructed to focus on contemporary conditions, illustrating how the past informed the present. Like other cultural workers of the era, they were meant to highlight aspects of a usable past-historical traditions that could be used to improve contemporary conditions - while paying the most attention to explaining what each community was doing "to carry on the democratic tradition." The culminating instruction Project leaders gave to writers was that the series as a whole

should have as the total effect, a feeling of the history, the land, the life, the struggle and the change in the peoples of America. Each writer will tell the story of his own area as the story he earnestly believes to be a part of our growth as a democracy. If this is done we hope finally to have a documented story of the root of America which must sustain us. ${ }^{33}$

To achieve this goal, all the programs of the RRP had to be understandable to the average American, and project leaders believed that to do so they would have to keep them simple, relatable, and accessible — an approach that would become a key practice in subsequent public history programming. For public-facing historians to effectively connect with an audience, they must present history in a way that endures or "sticks" with audiences. The best way to create ideas that draw viewers in and remain with them is to excite their imagination while also being relatable, for "information sticks when it offers elements people can relate to in their 
own experience." Therefore, content has to be packaged in ways that are accessible and meaningful, and which lead audiences to consider ideas and perspectives beyond those that they currently hold. ${ }^{34}$ One of the best ways to impart historical knowledge to diverse audiences, and one that the RRP often employed, is through stories.

Project leaders sought to teach listeners about American history-not just for the sake of history education, but also to challenge regional provincialism. They did so by encouraging listeners to think of themselves and their fellow citizens as belonging to one national community united by civic ideals, in ways that were both relatable and relevant to a diverse audience. Project leaders warned series writers against using grandiose language and instructed them to "tell a simple story" through the eyes of a particular individual "in dramatic and human terms." 35 As Philip Cohen explained, each episode of the Regional Series used stories of individuals and communities to highlight different cultural elements that either sustained or hindered the democratic process:

In this series of programs, we show the people, creating-changing and adjusting themselves to a constantly changing society. We show how community has reflected in its history and geography and every-day living, the development of the American Idea. We show how specific industries, land, the way of [life] and the culture of the people contribute to democracy and at the same time-if such be the truth-show why certain communities or parts of communities lack either a traditional or historical or economic background for democracy and how such shortcomings may lead to the establishment of undemocratic procedures and influence ... In short, we show, or we hope to show, the real significance of the big-concept words such as democracy, liberty, and America by breaking them down into their everyday manifestations in communities or regions throughout the country. ${ }^{36}$

As Cohen makes clear, while democracy has been an overarching national ideal, Americans had often failed, and often were still failing, to live up to this principle. For undemocratic forces to be defeated abroad, citizens would have to combat similar attitudes at home.

Each Regional Series script tended to follow a similar format, with a plainspoken narrator leading the audience through the history of the town or area into the present day. For example, in his script for a program on Williamsburg, Virginia, Joseph Liss opens with an African American narrator serving as a guide for the listening audience. After giving a brief history of the town, the narrator launches into a speech about American ideals and how the United States is "almost" a free nation. The problem, as he explains, is that no one is asking "what our slogans and phrases and heritage mean. Lump it all into big words ... call it Democracy-Liberty-or 
Technocracy." But, he continues, today is an ordinary day, so they are going to use ordinary people using plain language to "tell us the story of Williamsburg-Cradle of Liberty!"37 In another episode, "Rebirth in Murell's Inlet," Liss tells the story of the Revolutionary War through the history of a small town in South Carolina. The narrator explains, "That cannon fired at Concord was heard at Murrells Inlet. The people were good at revolting. They had tried it before. A hundred years beforewhen their Huguenot ancestors did and died for religious freedom and this godgiven right for men to govern themselves." 38

Other authors reinforced these themes as well. In her script "Nantucket Ahoy!" Jane Ashman writes a conversation between a young boy and the captain of a fishing boat. "Boy: Sounds like this island is pretty democratic. Captain: Democratic! Why, I think Nantucket invented democracy — clear back in the sixteen hundreds..." In the episode "Wyoming Valley," writer Oscar Saul tells the story of a rural area in Pennsylvania, beginning with a group of settlers in 1763 deciding whether to stay in the area or to move closer to colonial "authorities." During a town meeting, Eben (the hero) speaks up, declaring,

Do you know why you're staying man? Would you settle on the land of a Pennsylvanian proprietor and serve as his tenant? This valley is dangerous and wild, but it's free. We're the masters of our own land here-freeholders, not tenants and we're not governed by a lord of the manor. We govern ourselves! Does that mean nothing to you?

Furthermore, in keeping with the general emphasis on diversity and inclusion, Barney, the narrator of the episode, reiterates the episode's themes of democracy but also explains that this is not an exclusively Anglo trait, observing,

The valley has a gift of remembering. And it's a memory not only in the sons and daughters of the Yankee settler, who come by it thru the first struggle for freedom ... it's a memory in the Poles, and the Welsh and Irish and all the immigrants. Yes, freedom was found here but for the immigrants it was lost in the mine and had to be found again — and that it was found again — that's the glory of the parade. ${ }^{40}$

Although these scripts present a highly romanticized view of the past, they do illustrate periods of strife in American history - not just wartime problems, but also Irish labour strikes in the anthracite mines ("Wyoming Valley") and the Steamboat Monopoly fight in the New York Hudson Valley ("Hudson Valley" by Louis Lantz), both of which focus on the little people challenging their oppressors, which in these cases were the forces of capitalism. 
In their depictions of the American past viewed through the lenses of different regions, the writers of the Regional Series aimed to teach listeners of a people's history. The characters they created were the "nobodies" rather than great leaders. This celebration of the "nobodies" was particularly strong in Popular Front cultural products - most notably in the widely popular cantata, Ballad for Americans. With music and lyrics by left-wing composer Earl Robinson and lyricist John La Touche, and famously performed by Paul Robeson, the piece celebrates the "nobodies who are anybody" and the "anybodies who are everybody" as the hard-working Americans who both built up, and believed in, a democratic America. ${ }^{41}$ Furthermore, like the long list of ethnic groups qua Americans presented in Ballad for Americans, the Regional Series scripts paint a diverse portrait of the American people, emphasizing ethnic and racial diversity as intrinsic aspects of the national body politic, past and present. In his script on New Orleans, for example, Arthur Miller focuses on the city's diverse social makeup, concluding, "The Germans live next to the Spanish now and Negroes amongst them all. And in that is the power to build the new history of New Orleans." ${ }^{42}$ Although she does not reference the RRP programs, historian Judith Smith refers to broadcasts with messages like this as "the most characteristic" of Popular Front antifascist cultural products. She explains that radio programs of the Popular Front era reshaped

American history to stress ordinary people, rather than powerful and wealthy politicians and business leaders, as inventors and sustainers of American democracy. The most pointed interventions claimed racial heterogeneity as positive and racial justice as foundational rather than exceptional aspects of American history. ${ }^{43}$

Indeed, every episode of the Regional Series, regardless of the featured location, celebrated ethnic and racial diversity as well as cultural and political democracy as core tenets of the American ideal.

Because they were also instructed to teach Americans that maintaining democratic ideals was a continual process, some authors sought to comment on current injustices, albeit in subtle ways. In the notes for his script, Miller acknowledged that contemporary conditions in New Orleans fell far from American ideals. Wages and health conditions were abysmal, and what New Deal amenities had been installed, like Works Progress Administration (WPA) pools, were for whites only. He writes, "I shall not soon forget the sight of little Negro children standing outside a wire fence watching a crowd of white children playing in a WPA pool. The temperature that afternoon was 102." While these lines did not appear in the final script, Miller did have the narrator, when reflecting on the changes in the city after the Civil War, state, "I kinda feel now that the war is done, that a new day is dawnin' over New Orleans. I think we ought all to work together toward more democracy, 
a better chance for all people in the South." Considering that Miller imbues the script as a whole with references to the important roles that African Americans played in the historical development of New Orleans, the emphasized "all" is an unmistakable call for racial inclusivity. ${ }^{44}$

This stress on valuing diversity and inclusion as American ideals was woven throughout all the RRP programs, not just the Regional Series. For example, the program Hidden History - a series of fifteen-minute episodes aired on Sunday afternoons on NBC from May through November 1941—was designed to provide personal perspectives on the lesser-known stories of the American past and present. Culled from letters and other documents in the Library's collections, each episode recounted historical events from a grassroots vantage point. One episode, aired on June 29, 1941, tells the story of the construction of the Panama Canal through the domestic and physical hardships that people who went to work on the canal endured. The story focuses on the experiences of two primary characters: Bill, a digger, and his wife, Helen, both from Brooklyn. "The Story of Immigrants," aired on July 13, 1941, opens with the announcement, "We bring you the story of the American people_-a story of the immigrants..." The episode highlights various representatives from different ethnic groups to explain the reasons they came, such as the desire for land or seeking employment opportunities. The program begins with immigrants to the Jamestown Colony recounting the story of Polish immigrants in the English colony who fought for the right to be represented in the House of Burgesses. As with other episodes in this and other RRP programs, there is a distinctly anti-elitist bent, with the "gentlemen" of the colony portrayed as lazy and the heroes being poor Polish, Norwegian, Bohemian, and Portuguese immigrants who paid for their steerage and worked hard - in trades, on the land, and at sea. ${ }^{45}$

Recounting major historical events and processes through the eyes of ordinary historical actors was yet another way to draw audiences in and make the content more relatable to contemporary listeners. Immigrants, labourers, men, women, city folk, and rural residents could all potentially see themselves and experiences similar to their own represented in these articulations of the past. This would, presumably, make these historical events more meaningful to the listening audience. Furthermore, Hidden History was in line with a people's history approach because it was predicated "on the thesis that history is found not only in books and manuscripts in public libraries but in the minds and memories of the people," according to Charles Harrell. ${ }^{46}$ Philip Cohen wrote, in a draft prospectus for the series, "The program operates on the principle that history is told in the lives of the ordinary people. What people believe, what they see, what they do constitute history. Each program in the series investigates some of those things in which people believe, whether fact or not." 47 The purpose was not to portray an objective view of the past, but rather to show how historical actors viewed and interpreted the larger events, issues, and institutions that shaped their lives. 


\section{Folklore and Folk History}

To ensure that the Hidden History series truly represented the perspectives of the people, the announcer stated at the beginning of episodes that the existing documentary record in the Library - which provided the historical basis of each showwas incomplete. To create a more representative record, he asked that listeners "supply information which completes the stories we tell or throws new light on the events which we dramatize here." 48 Readers responded by mailing items such as diaries, letters, and other ephemera. ${ }^{49}$ Since Hidden History editor Alan Lomax was a folklorist, it is hardly surprising that he specifically wanted listeners to send in local folktales and songs that they knew from their own families and communities. For example, the episode on the Erie Canal dealt almost exclusively with folklore and folksongs that address the social, cultural, and economic changes the canal wrought. Listeners were then asked to contribute their own folksongs and stories "relating to the land, the life and the people of the canal." ${ }^{50}$ Folklore, according to RRP officials, provided perhaps the most direct insight into the people's past. Nobody exemplified this belief more than Lomax, who, in addition to editing Hidden History, was the Assistant in Charge of the Archive of American Folksong (AAFS) at the Library of Congress, and served as Consultant in Folklore for the RRP as a whole.

In 1933, as a teenager, Alan Lomax began what would become a long career in folklore when he accompanied his father on a song-collecting trip around Texas, funded by the AAFS. His father, John Lomax, was by then a well-known song collector who had established his reputation with the 1911 publication of Cowboy Songs and Ballads, a collection of cowboy songs for which he had provided the music and anecdotal annotations. By the mid-1930s, Alan Lomax had launched his own career, conducting song-collecting trips in regions throughout the United States as well as in the Caribbean. In 1937, Alan Lomax accepted the position at the AAFS, while his father served as Honorary Consultant to the archive. Both Lomaxes were key advocates of public-facing or applied folklore and sought to turn the AAFS into a repository that would preserve American folk music and make it available to a public audience. According to folklorist Robert Baron, applied folklorists "disseminate[d] folkloristic knowledge beyond the academy, furthering social and political agendas while acting in the presumed interest of communities." As a member of the applied folklore generation of the 1930s, Alan Lomax believed that folklorists should play an interventionist role (protecting and revitalizing threatened traditions) and an advocacy role for and alongside the communities that they worked among. ${ }^{51}$ Unlike their academic peers, applied folklorists like Lomax directed their work to the general public by publishing popular anthologies of folklore, writing about folklore in magazines for adults and children, hosting folk radio programs, and working in government agencies like the AAFS and WPA programs.

Much like the study of history, the study of folklore has a long history. During the late nineteenth century, scholars in both fields worked to professionalize 
their subjects. As folklore morphed from an amateur endeavour into a scholarly pursuit, European folklorists continued the longstanding emphasis on collecting the traditions of rural peasant communities. Their American counterparts turned their attention to the cultures of Indigenous peoples; this opened the field to the study of non-Western groups, breaking from its Eurocentric focus. In the United States, the new generation of scholarly-trained folklorists divided into two camps: literary folklorists and anthropological folklorists. According to folklorist Rosemary Levy Zumwalt, literary folklorists maintained a broad interpretation of what constituted folk traditions, arguing that all aspects of traditional practices ought to be considered, whereas anthropological folklorists focused almost exclusively on "verbal art or oral literature" - such that anthropological folklorists broadened the category of what constituted a folk group while literary folklorists broadened the concept of what folk culture was. ${ }^{52}$

In 1888, a cohort of scholarly folklorists including Francis James Child, William Wells Newell, and Franz Boas moved beyond their academic settings to form the American Folklore Society (AFS), which would become the most significant folklore organization in the country. ${ }^{53}$ According to folklorist Regina Bendix, the original founders viewed their work as a necessary cultural intervention to collect and record precious cultural artifacts that they feared were dying out. To increase members, respectability, and funds, the AFS encouraged the formation of local chapters. However, these chapters often catered to the needs of their members, most of whom were uninterested in maintaining scholarly or academic standards. ${ }^{54}$ Folklorist D.K. Wilgus explains that many of these members could be classified as "local enthusiasts." Rather than studying and classifying folk traditions according to academic standards, they often romanticized the traditions they collected, emphasizing their perceived cultural primitivism and exoticizing tradition bearers as cultural Others to public audiences. ${ }^{55}$ While the AFS originated among academics, during the early twentieth century it became a decentralized organization with chapters scattered around the country, many of which maintained differing views of what constituted folk traditions and how best to preserve them.

Interest in folklore was high in popular culture throughout the early twentieth century, as evidenced by the rise of amateur song collectors, folk festivals, and folklore societies even beyond the AFS chapters. ${ }^{56}$ All the while, folklorists in university settings tried to maintain some kind of scholarly standards in training those who pursued the academic study of folklore. By the time applied folklore solidified in the 1930s, folklorists of this ilk operated within a middle ground between the academics and the popular fans of folklore. They were trained in the discipline but directed their work to a general audience, and they advocated for a popular appreciation that did not flatten the complexities of regional traditions or objectify the tradition bearers. During this period, folklorists in public agencies and even those working in academic institutions were also concerned with protecting and conserving folk traditions that they feared were ebbing away as traditional communities be- 
came more connected to commercial media. Alan Lomax and other applied folklorists believed that the best way to preserve these traditions was to get people interested in them so that they would be more apt to appreciate and practice them in their own lives, thus keeping the traditions alive.

By the mid-1930s, applied folklore also began to develop a strong political connotation. Lomax was part of a cohort of applied folklorists working for the federal government that had strong ties to the Popular Front. The activist members of the Washington "folk establishment," as Benjamin Filene refers to them, included folklorists like Benjamin Botkin and musicologists like Charles Seeger. These folklorists argued that folk traditions were not antiquated art forms, but were rather "contemporary proletarian protest about social conditions," according to folklorist Alan Jabbour. ${ }^{57}$ Lomax and other Popular Front era collectors viewed folk music as the people's means to safely express their anger and protest their conditions. ${ }^{58}$ Many of the communities in which Alan Lomax and his father worked were socially, economically, and politically marginalized: African Americans in the Deep South, Dust Bowl migrants, incarcerated citizens, farmers relocating through the Resettlement Administration, and ethnic communities in both rural and urban areas. Similarly, Charles Seeger worked to record the music of displaced farmers in the Resettlement Administration (the precursor to the FSA), and Benjamin Botkin led the WPA Writer's Project program of collecting slave narratives. They and other public folklorists in the Washington Establishment were staunch progressives who believed that folk culture-music in particular-had the power to bring the voices of these marginalized groups to a public audience, enabling them to speak for themselves. This would serve to democratize American culture, generate awareness of political, social, and economic inequality, and hopefully lead to social and political reform.

As a leading figure in the RRP, Lomax ensured that folk music was featured in virtually every program. Even writers of the scripted Regional Series had explicit instructions to include folklore and folksongs from the regions they depicted. ${ }^{59}$ Lomax had a clear rationale for this emphasis, explaining that until the RRP, the voices of the people (folk groups) had been largely absent in mass media. In the Report of the Radio Research Project pertaining to the 1941-1942 season, Lomax claimed that the RRP staff members collectively believed that American radio had created a void through "its failure to draw on the rich background of regional speech, music, and history." "Metropolitan"_ _ or commercial_culture had been dominant in terms of radio play, which meant that regional voices, especially from rural areas, were silenced. Further compounding the problem, mainstream radio programs' attempts to include "local colour" segments usually based them on offensive stereotypes. To counteract this, the RRP staff sought to enable the people to speak for themselves by recording them and broadcasting those recordings through different RRP programs. Since live regional programs were too expensive, they decided that sending out staff to collect field recordings would be the best strategy. To facilitate this, the 
RRP dispatched folklorists to a carnival in rural Maryland, to a folk festival in Asheville, North Carolina, to a rural county on the verge of being flooded for a Tennessee Valley Authority (TVA) project, and to Federal Security Agency Camps for dustbowl migrants in southern California. ${ }^{60}$

The RRP even featured a program that centred exclusively on folk music. Distributed by the Federal Radio Education Committee, the US Office of Education, and the Federal Security Agency, the program The Ballad Hunter showcased field recordings that John Lomax had collected for the AAFS. In his description of the show, Harrell emphasized its significance: "possibly for the first time in radio, American folk music is heard sung by authentic singers." ${ }^{61}$ Authenticity, in this case, meant that tradition bearers, rather than trained musicians, performed the songs. The show was arranged thematically, with each episode centring on a different musical theme, such as southern African American spirituals, New England sea shanties, canal songs (mainly about the Ohio Canal), songs about the boll weevil scourge, southern prison songs (primarily from the Arkansas State Penitentiary), and labour songs (concerning forms of labour such as logging, cowboy work, railroad work, and cotton-picking). ${ }^{62}$ Although the featured musicians were all tradition-bearers, the material was mediated through the perspective of John Lomax, who, as the show's narrator, explained the historical and cultural significance of each song as well as his own experiences collecting them.

C.A. Siepmann wrote favourably of The Ballad Hunter, explaining that it was "self-justified as 'archive' material of national and historical importance" that had particular relevance and value for classroom education. Siepmann recognized that the RRP leaders cast folk traditions as reflections of the past that, rather than existing as archaic vestiges, continued to be important aspects of contemporary regional cultural practices. This interpretation of folklore had become common among public folklorists in Washington who worked in the RRP, the AAFS, and different cultural programs within the WPA. Benjamin Botkin, who served as the national folklore editor of the Federal Writers Project and succeeded Alan Lomax as the head of the AAFS in 1942, was one of the strongest proponents of interpreting folklore and folk music as examples of social history, and as reflections of contemporary circumstances. Botkin argued in 1940 that folklore was "living lore" or "folklore in the making," and therefore "has a more direct relation to contemporary or recent social structure and is the expression of social change and cultural conflict." Furthermore, because of the traditional emphasis on the deeds of famous men in academic history, the people of folk communities had been largely omitted from the historical record, such that folkways provide one of the few means of accessing the history of underrepresented people. Advancing a view similar to Carl Becker, who had been president of the American Historical Association (AHA) in 1931, Botkin stipulated that the history found in folklore was "a history also in which the people are the historians as well as the history, telling their own story in their own words_-Everyman's history, for Everyman to read." It was a people's his- 
tory that effectively illustrated how the past continued to inform the present. ${ }^{63}$

This emphasis on "Everyman's" history was a common thread running through each of the RRP programs. While this was particularly acute in the folklore programs, even shows focused on historical leaders shifted perspective from Great Man history to larger historical contexts, by showing how the figures affected the circumstances of their eras and how ordinary people perceived them. For example, one proposed show, titled "The American Tradition," was to be a series of biographical documentaries of famous leaders (scientists, writers, jurists); but, rather than focus on their writings, the show would depict their influence on the periods in which they lived. The source material for this show would be newspapers, popular songs, theatre billboards, and popular fiction - materials that everyday people produced and consumed. ${ }^{64}$

While the historical scripted programs consistently represented a people's history, the folklore programs took it a step further by enabling the people to speak for themselves - a point that the narrators of the folklore programs often reiterated. In the program "Looking for a Home," based on recordings taken in 1941 at the Federal Migratory Labor Camps in California, the narrator explains that it is a show similar to The Grapes of Wrath, in that it is about farming families pushed out of their Midwestern homes and into California by the dustbowl. However, it stipulates that it "is the story in their own words and in their own songs." 65 At the beginning of the show "America in the Summer (1941)," which was based on recordings conducted in black and white communities of rural Delaware, the announcer explains that the songs and stories heard on the show are presented by the people themselves and "not through an actor's voice." In case this was not explicit enough, the announcer continues, "This is not a public opinion [poll]; it is more. You will hear your own neighbor talking for himself, not an actor. And here is your reporter to bring you the voices of your neighbors in the Summer of 1941." The recordings in Delaware were just one part of the series, as sound trucks were also sent to Texas and California. The RRP staff edited the recordings from this summer into six fifteen-minute documentaries, which were aired on sixty local stations. They never made it to the major networks, but did have some regional popularity, particularly in the South. ${ }^{66}$

Programs that focused on field recordings clearly emphasized contemporary conditions and concerns, but even they attempted to connect the past to the present. The show "Report to the Nation," about how Washington was addressing citizens' concerns, explained, "The record is not finished. Living history never is. But what you have just heard is a segment of our history as it is actually being lived by people like your own neighbors-1941 Americans." ${ }^{67}$ By emphasizing the connection of the past to the present, the RRP illustrated the long history of American ideals, and showed how civic ideals were rooted in American heritage and continued to inform contemporary life. It was also a strong propaganda tactic on the eve of the US entry into the Second World War. 


\section{Oral History and Wartime Propaganda}

In January 1942, RRP Chief Philip Cohen wrote to Archibald MacLeish that, because of the war, the RRP was revamping the programs: "More of our efforts were concentrated on documentary activities in an effort to gather and disseminate material based on the actual recordings of a people about to enter, and, finally, entered in the War." ${ }^{68}$ What is interesting about this statement is not that the RRP was altering its focus to that of the war effort, but rather that Cohen seems to note that this is a new shift. Many RRP documentarians had been asking Americans about their views of the war and potential US involvement. Furthermore, the programs had been articulating a form of civic nationalism that was prominent in government wartime propaganda-particularly involving Americans' views on democratic ideals-from the outset.

During the sound truck expeditions in the summer of 1941, Alan Lomax conducted a series of field recordings around the Southeast, recording folk festivals and interviews in areas affected by the TVA. On the recordings, Lomax repeatedly asks interviewees what they think democracy is, whether they think the United States is democratic, and what could be done to enhance American democracy. During a festival in Asheville, North Carolina, one male interviewee responds, "Democracy to me means freedom of speech, freedom of press, and freedom to do what I please so long as I do not harm someone else." Statements like these were presented wholly in the show, but anything that smacked of isolationism or opposition to America's entry in the war was cut. Editors decided to omit from the final transcript the comments of one interviewee-self-identified as a Republican-who voiced his opposition to the US selling munitions to other countries and his view that the country should keep the troops home and remain neutral. ${ }^{69}$

As a program dominated by liberals and Popular Front leftists, it is not surprising that all RRP hands were on deck for the war effort by the end of 1941. Following the attack on Pearl Harbor, Alan Lomax acted almost immediately. On December 8, he sent identical telegrams to John Lomax (Texas), Vance Randolph (Missouri), John Faulk (Texas), Charles Moore (Massachusetts), Duncan Emrich (Colorado), Charles Johnson (Tennessee), Leland Coon (Wisconsin), and Bob Allen (Indiana), requesting the following: to get "within 48 hours recordings of reactions of four or five average men and women to Japanese aggression. Get colorful people who speak well. Library will pay costs of discs which will be used for historical record and possibly radio broadcast." ${ }^{, 70}$ Most of the people interviewed seemed somewhat squeamish about war but thought that the US had been forced into it and now supported mobilization. One of the interviews was with two African American bricklayers in Washington, DC. The first interviewee stated, "So far as my concern, this country is involved in a war, and I think we should be patriotic citizens of the United States of America regardless of creed, color, and condition." This interviewee continued to reflect on race relations, stating on the one hand, "I feel that the white men are our friends. I know that we are a friend to the white 
man" and that they should fight together. On the other hand, his companion stated that African Americans would "do their very best" but only if they had a chance to do so-an opportunity not yet given. ${ }^{71}$

Much of this material shaped the two main programs Lomax developed after the US entered the war: "December $7^{\text {th" }}$ and "Dear Mr. President." In the latter program, aired in May 1942, average Americans spoke of their views on democracy, their local communities, and the country as a whole. While many people expressed support for the war and the war effort, the show was careful not to present them as a homogeneous mass of wartime zealots. The narrator made this clear: "they're not all standing in a straight line waving flags and talking like a bunch of parrots. No, Mr. President, they've got their own ideas about what they're fighting for and what they don't like, they're ready to tell you." This segued into people expressing fears of war profiteering and anxiety about what kind of society the soldiers would return to after the war. ${ }^{72}$

Many of the interviewees reflected on the gross inequalities in American life, illustrating Philip Cohen's view that in many ways the country was not living up to its democratic ideals. David Helfeld, a nineteen-year-old college student and president of the College of the City of New York student council, stated in his message to the president,

There's just one thought I'd like to get across to you. It's a feeling, which horrifies all the boys at our college, and that is Negro discrimination in the Army and Navy. It seems to me to be an example_-a very horrible example_ of fascism within democracy. When we here at the college hear that there are Negro-purely Negro_-regiments and that Negroes are only allowed to do slop duty on the battleships of our navy, it makes us feel very bad. We realize that there [is] the physical war against the fascist nations $\ldots$ and the war from within against anti-Semitism, Jim Crow, and factors of that nature. We feel that as long as there is fascism at home, it is rather futile to fight it on the outside when we are not fighting it from within. ${ }^{73}$

W.C. Curry, an FSA Fellow in Nashville, shared this sentiment. He believed the "unpreparedness of the United States" for the attack on Pearl Harbor was "mainly due to the pro-fascist forces within this country." He continued,

This is the gravest period in our country's history. One of the gravest dangers is not from abroad but lies in those fascistminded forces from within ... The Negro, as in every other crisis in this nation's history will laudably distinguish himself in the defense of these United States-his country. And we will also 
equally share in the better world which the ultimate victory will bring. ${ }^{74}$

Several African American interviewees also observed the rampant discrimination in America but said that they would support the country during the war. In a series of interviews conducted in Nashville, Tennessee, Congregational minister Rev. W. J. Faulkner observed that for "too long have we been divided at home ... in practices of stupid and costly racial discrimination." He hoped that the American people would be "galvanized into effective action by uniting all of our people and resources on a basis of equality into one invincible army of patriots." Fadie France, a secretary for the YWCA, also stated that she had an unflagging faith in the United States, "even though the treatment of minority groups has been and still is unfair." Walter Hadley, an attendant at Vanderbilt Hospital, was even more direct, stating,

I also feel, as a Negro, that our boys should have a better place in the Army and Navy since we all have to fight together. We should fight more for a solidarity in this country-declare war on that nation in Dixieland-to help us all have one common cause to fight for: liberty, equality, and justice for all! ${ }^{75}$

Another interviewee from Austin, Texas, who was a private in the Army, also called out the South as a region steeped in racial discrimination, noting "The Negro realizes that in the past he has not got the promises that was [sic] made to him in the Declaration of Independence or in the emancipation of slaves. Because at times the Negro is still treated as he was before these things happened." ${ }^{, 76}$ Clearly, these people indicated that for the country to fight undemocratic forces abroad, something had to be done about similar conditions on the home front. ${ }^{77}$

While many, if not most, of these interviews did not make it to the radio, their collection and preservation in the Library of Congress is itself significant as a documentation of people's views on the promises and failures of American democracy. The radio programs that Lomax developed from the interviews-edited though they were-still reflected the RRP's emphasis on grassroots social perspectives. In a letter to Lomax, folklorist Fletcher Collins commended him for using radio to reflect on contemporary circumstances. Collins encouraged other folklorists to engage in similar projects because doing so

opens up a field which has not been touched by the radio, and a field of enormous importance to Americans. It heightens their consciousness of themselves as Americans, and it contributes vitally to civilian morale in expressing what the common people of the nation are feeling and thinking, an expression of others than governmental leaders, radio commentators, and newsmen. ${ }^{78}$ 
Discussions of race and racial discrimination were not entirely absent on the radio at this time, as evidenced by the strident commentary of activists like Langston Hughes and Richard Wright on America's Town Meeting of the Air. ${ }^{79}$ But the significance of "Dear Mr. President" is that the voices featured were those of ordinary Americans reflecting on their personal experiences in regions throughout the country, rather than of public intellectuals.

Collins's observation that these programs would enhance civilian morale illustrates the shift in focus among the RRP staff during wartime mobilization. Lomax and other public folklorists had worked to infuse folk traditions into cultural programs prior to the war, and now they turned their attention to ensuring that these same traditions were incorporated into wartime propaganda. As mobilization reached a fever pitch in the Federal government, the DC folklorists realized that in order to keep their projects going, they had to move from simply documenting "the American people's culture" to shaping it in a way that would be clearly beneficial for the war effort; this is when the RRP explicitly turned into wartime propaganda. The programs became more scripted, and the pro-democracy, pro-Allied rhetoric grew even more pronounced. ${ }^{80}$ But, again, it was a kind of rhetoric that still was in keeping with the democratic pluralism and antifascism that leftists promoted during the Popular Front of the 1930s and its wartime revival. After 1941, RRP programs like the interviews for "Dear Mr. President" continued to illustrate the emphases on the struggle for political equality and social justice that characterized Popular Front Americanism. ${ }^{81}$

\section{Popular Reception}

Although the RRP programs were intended for popular audiences, interest was highest among educators, as revealed in feedback that the RRP received. In order to assess the response to the programs, RRP staff distributed surveys to local radio stations to find out what worked in certain programs and why. When the RRP sent out copies of the program "Americans Talk Back," for instance, they included a questionnaire asking what recipients thought of the program, whether they thought it was a worthwhile project, which episodes they liked the best, and whether they received any listener feedback. Most of the response sheets that the RRP kept on file were positive in nature. Only one, from Alaska, didn't use the material because the interviewees discussed their feelings on the potential of going to war, which was no longer relevant once the US had entered the conflict. Elizabeth Goudy, the director of radio for Los Angeles County Schools, wrote a glowing review detailing how the summer school of the University of Southern California incorporated the program into their curricula. Specifically, they used the show in teacher-training programs to show what could be done in the field of documentary work, and they thought the programs were "extremely valuable to an understanding of the groups in our society which comprise America. High school teachers of social problems and sociology can make valuable use of these [shows]." ${ }^{22}$ Educational demand was 
also high for the Hidden History series. So many teachers wrote in requesting transcripts of the shows for their classes that RRP staff had to write back that the demand was so high that they could only send a few at a time. ${ }^{83}$

Ultimately, the RRP was a product of the Popular Front's antifascism and celebration of the people, and it ended with the close of that era. More specifically, the termination of the program began in January 1942 and concluded the following month, after MacLeish accepted an assignment to direct the Office of Facts and Figures, and Lomax soon left the Library for the Office of War Information. Many RRP members continued to uphold the main ethos of the project in their subsequent work, but the scale of this radio documentary project would not be replicated at the Library. For the duration of the project, leaders were guided by the idea of a usable past and sought to use that past to influence Americans' views of the ideas and principles that, according to project leaders, lay at the heart of the American Idea. Every program presented a people's perspective on both American history and current events - an approach that often gave voice to those who had been, and continued to be, marginalized citizens. In this sense, the project maintained the pluralist, collaborative, and socially progressive ethos of the Popular Front, even during its interim from 1939 to 1941, thus illustrating the depth — and duration-of the Popular Front movement in the United States. Ultimately, RRP leaders attempted to use the power of radio to introduce Americans of various backgrounds to each other- - to make the imagined community a little more real and to unite the country through a simultaneous celebration of cultural and political democracy, and a commitment to ensure the application of these civic ideals to all citizens.

In many respects, these are the same objectives that undergird contemporary practices of public history in the United States, particularly those identified by the National Council on Public History as "on-going commitments of many current practitioners to ideals of social justice, political activism, and community engagement." ${ }^{\text {" } 4}$ While many of these ideals were at the core of the social justice movements of the 1960s, they were clearly important components of left-wing Americanism during the Popular Front period of the Old Left. Tracing these efforts from the emergence of professional public history during the 1930s to the solidification of the field in the 1970s reveals ideological continuities between these two periods of activism, in addition to exposing a far longer foundational history of public history in the United States. 


\section{NOTES}

${ }^{1}$ G. Wesley Johnson, "The Origins of the Public Historian and the National Council on Public History," The Public Historian 21, no. 3 (Summer 1999): 168.

2 Ibid., 167-170, 174; Rebecca Conard, "The Pragmatic Roots of Public History Education in the United States," The Public Historian, 37, no. 1 (February 2015): 115-116; Marianne Babal, "Sticky History: Connecting Historians with the Public," The Public Historian 32, no. 4 (Fall 2010): 77-78; Arnita A. Jones, "Public History Now and Then," The Public Historian 21, no. 3, (Summer 1999): 27. For accounts that point to the 1960 s as a critical period for shaping professional public history, see Richard Rabinowitz, Curating America: Journeys through Storyscapes of the American Past (Chapel Hill: University of North Carolina Press, 2015), and David Glassberg, Sense of History: The Place of the Past in American Life (Amherst: University of Massachusetts Press, 2001).

${ }^{3}$ Denise Meringolo, Museums, Monuments, and National Parks: Toward a New Genealogy of Public History (Amherst: University of Massachusetts Press: 2012), is one of the most in-depth historical examinations of the rise of public history in the United States. In 2013, a cohort of public historians began a working group to explore the politically radical origins of public history prior to the 1960 s. Led by Meringolo, The Radical Roots of Public History project consists of over twenty public historians who are examining the political radicalism of museum studies, grassroots history, oral history, and public history pedagogy. The author of this piece is involved in the pedagogy of public history groups.

${ }^{4}$ Examples of these early cultural antiquarians include early preservation groups of the late nineteenth and early twentieth centuries like the Mount Vernon Ladies Association and the Society for the Protection of New England Antiquities, that sought to use the homes of founding fathers and early Americans to Americanize the immigrant working class. This was a sentiment shared by the monument public art enthusiasts of the City Beautiful Movement. A key aspect of these efforts was the preservation and creation of tangible objects that would be permanent features on the cultural landscape. Other preservationists, particularly in the realm of folklore like Cecil Sharp and Olive Dame Campbell, worked to preserve the intangible resources of folk groups - namely the songs of white, Appalachian mountaineers - as aspects of authentic Anglo folklore that they presumed was in danger of being eradicated as the allegedly "isolated" mountain residents grew more connected to mass culture.

${ }^{5}$ Historians of the field have noted how significant the New Deal has been for public history. See Meringolo, Museums, Monuments, and National Parks; Daniel Bluestone, Buildings, Landscapes, and Memory: Case Studies in Historic Preservation (New York: W.W. Norton \& Company, 2010). 
${ }^{6}$ Alan Gevinson, "What Neighbors Say': The Radio Research Project of the Library of Congress," Performing Arts Broadcasting (Winter 2002): 95.

${ }^{7}$ Michael Denning, The Cultural Front: The Laboring of American Culture in the Twentieth Century (New York: Verso, 1996), 4, 9.

${ }^{8}$ In many respects, the rise of public folklore coincided with the rise of public history as a response to a job crisis as well as rising interest in marginalized communities during the 1970s. See Steve Siporan, "On Scapegoating Public Folklore," Journal of American Folklore 113, no. 447 (Winter 2000): 86-89. According to folklorist Dan Ben-Amos, applied folklorists set the precedent for the emergence of public folklore during the Depression era. See Dan Ben-Amos, "The Name is the Thing," Journal of American Folklore 111, no. 441 (Summer 1998): 264-65.

${ }^{9}$ Frederick J. Stielow, "Librarian Warriors and Rapprochement: Carl Milam, Archibald MacLeish, and World War II," Libraries \& Culture 25, no. 4 (Fall 1990): 513; "MacLeish Appointment Protested," ALA Bulletin, 33, no. 7 (July 1939): 467. ${ }^{10}$ Historian Bruce Lenthall argues that network executives would often censor works by individual artists for being too political or controversial. The only time that writers had more leeway in expressing their views-especially protesting fascism and supporting civil rights_-was during the brief window of the Second World War, when such sentiments fell in line with wartime propaganda. See Bruce Lenthall, Radio's America: The Great Depression and the Rise of Modern Mass Culture (Chicago: University of Chicago Press, 2007), 183-190. However, these ideas did not emerge from the propaganda campaigns but rather were shaped by the antifascist and pro-civil rights rhetoric that leftists had been promoting during the decade of the Popular Front.

${ }^{11}$ James R. Barrett, "Rethinking the Popular Front," Rethinking Marxism 21, no. 4 (2009): 531-534. Similarly, John Diggins argues that the Left in the 1930s arose in response to the Depression, and global circumstances led American leftists to join with the Communist Party, namely the rise of fascism. See John Diggins, The Rise and Fall of the American Left (New York: W. W. Norton, 1992), 150-151, 174. The traditionalist Harvey Klehr also argues that around 1933, socialists, radicals, and liberals entered into the Communist fronts with the unified goal of defeating fascism. Klehr even recognizes that fellow travellers were not "duped," but rather entered coalitions to further a program that they believed in, recognizing that unity was necessary to achieve that goal. See Harvey Klehr, The Heyday of American Communism: The Depression Decade (New York: Basic Books, 1984), 107, 207, 217. By the mid-1930s, as Maurice Isserman argues, it was perhaps even easier for the CPUSA to advance the Popular Front coalitions when Roosevelt had shifted to a left-of-centre position with the second New Deal. See Maurice Isserman, Which Side Were You On?: The American Communist Party During the Second World War (Middletown: Wesleyan University Press, 1982), 3. This was in contrast to the first 
New Deal—marked by relative conservatism and service to business interestswhich started driving progressive liberals to seek left-wing alternatives in the first place, according to Richard Pells. See Richard Pells, Radical Visions and American Dreams (New York: Harper and Row, 1973), 86.

${ }^{12}$ Barrett, "Rethinking the Popular Front," 533-539. Barrett recognizes that the traditional (and largely anti-Communist) view holds that the Popular Front was merely a result of Party officials and the rank-and-file following orders from Moscow. But this view ignores the grassroots work in which ordinary Communists had previously engaged with other left-wing groups. This was especially true among Communists in Spain and France, who encountered powerful fascist forces. Barrett argues that historians can understand this dynamic by adopting a ground-up view of the Party even before the Popular Front. Like their counterparts in Spain and France, members of the CPUSA already began collaborating with other groups during the Third Period. Barrett points to collaborations between Communists and Socialists in California during the longshoremen uprisings of 1934, and a similar collaboration formed in Chicago's 1933 unemployment movements. Even young Communists formed alliances with socialists, as was the case with the Young Communist League a year prior to the Popular Front. All of these actions occurred without the official sanction of - and sometimes in direct opposition to-CPUSA leadership.

${ }^{13}$ Ibid., 540. From 1930 to 1943, the percentage of women had grown from ten to fifty percent, and women held one-fourth of the seats on the Central Committee.

${ }^{14}$ Ibid., 542.

${ }^{15}$ Michael Denning, "Afterword: Reconsidering the Significance of the Popular Front," Rethinking Marxism 21, no. 4 (2009): 554.

${ }^{16}$ Denning, The Cultural Front, 9.

${ }^{17}$ Stielow, "Librarian Warriors and Rapprochement," 519-520.

${ }^{18}$ Gevinson, "What Neighbors Say," 98-99.

${ }^{19}$ Charles T. Harrell, "The Library of Congress Radio Research Project," ALA Bulletin 35, no. 7 (July 1941): 448; Gevinson, "What Neighbors Say," 95-96.

${ }^{20}$ Douglas B. Craig, Fireside Politics: Radio and Political Culture in the United States, 1920-1940 (Baltimore: The Johns Hopkins University Press, 2000), 214-215.

${ }^{21}$ Michele Hilmes, Network Nations: A Transnational History of British and American Broadcasting (New York: Routledge, 2012), 122. Two of the key members of the RRP, Philip Cohen and Charles Harrell, both held Rockefeller Fellowships at the BBC in 1938, which explains the British influence (129).

${ }^{22}$ Gevinson, "What Neighbors Say," 95. By as early as 1935, American listeners were familiar with hearing fellow citizens' voices over the airwaves through quiz 
shows, musical programs like Major Bowes' Original Amateur Hour, on-the-street interviews in programs like Vox Pop, and as contributing audience members on America's Town Meeting of the Air. However, the voices that listeners heard were not contextualized, as they were on RRP programs. See Jason Loviglio, Radio's Intimate Public: Network Broadcasting and Mass-Mediated Democracy (Minneapolis: University of Minnesota Press, 2005), 38-39).

${ }^{23}$ Hilmes, Network Nations, 106.

${ }^{24}$ Gevinson, "What Neighbors Say," 100.

${ }^{25}$ Lenthall, Radio's America, 56-57; Elena Razlogova, The Listener's Voice: Early Radio and the American Public (Philadelphia: University of Pennsylvania Press, 2011), 34; Craig, Fireside Politics, 86-88.

${ }^{26}$ Loviglio, Radio's Intimate Public, xix.

${ }^{27}$ Lenthall, Radio's America, 176, 180. MacLeish's The Fall of the City, an antifascist radio play that debuted in 1937 on The Columbia Workshop, was groundbreaking enough to lead critics and listeners to recognize that "radio deserved serious creative consideration."

${ }^{28}$ Barbara Dianne Savage, Broadcasting Freedom: Radio, War, and the Politics of Race 1938-1948 (Chapel Hill: UNC Press, 1999), 21.

${ }^{29}$ Lenthall, Radio's America, 14.

${ }^{30}$ Benjamin Filene, Romancing the Folk: Public Memory and American Roots Music (Chapel Hill: UNC Press, 2000), 148, 151.

31 "Outline of Proposed Defense Activities for the Radio Research Project," Folder: Radio Research Project, General, Box: Radio Research Project, AFC 1941/005, Radio Research Project Manuscript Collection, Folklife Center, Library of Congress, Washington, DC [hereafter RRPMC].

32 "General Statement of Plan to Script Writers Working on Regional Documentary Programs," 1, Folder: Untitled, Box: 3, RRPMC.

33 "General Statement of Plan to Script Writers Working on Regional Documentary Programs," 1-2, Folder: Untitled, Box: 3, RRPMC. The term "usable past" refers to an interest in using history either to better understand or to reform contemporary conditions that first developed among First World War-era public intellectuals like Randolph Bourne and Van Wyck Brooks, who coined the term. Brooks believed that if the past had no relevance to the current times, then it was useless. See Alfred Haworth Jones, "The Search for a Usable American Past in the New Deal Era," American Quarterly 23, no. 5 (December 1971): 711.

${ }^{34}$ Babal, "Sticky History," 80-82; Rabinowitz, Curating America, 151.

35 "General Statement of Plan to Script Writers Working on Regional Documentary Programs," 1.

${ }^{36}$ Joseph Liss, "Regional Series," Report of the Radio Research Project, The Library of 
Congress, January 1941-February 1942, RRPMC

${ }^{37}$ Liss, "Williamsburg, VA," draft, December 15, 1940, 3-4, Folder: Williamsburg, Box: 3/5, RRPMC.

${ }^{38}$ Liss, "Murrell's Inlet," 4, Regional Prospectus of the Radio Research Project, Library of Congress (January 7, 1942), RRPMC.

${ }^{39}$ Jane Ashman, "Nantucket Ahoy!," first draft, April 21, 1941, 6, Regional Prospectus, RRPMC.

${ }^{40}$ Oscar Saul, "Wyoming Valley," second draft, April 21, 1941, Regional Prospectus, RRPMC.

${ }^{41}$ Earl Robinson and John La Touche, Ballad for Americans (Federal Theatre Project, 1939).

${ }^{42}$ Arthur Miller, "New Orleans," fourth draft, April 21, 1941, 30, Regional Prospectus, RRPMC.

${ }^{43}$ Judith E. Smith, "Radio's 'Cultural Front,' 1938-1948” in Radio Reader Essays in the Cultural History of Radio, ed. Michele Hilmes and Jason Loviglio (New York: Routledge, 2002), 210.

${ }^{44}$ Arthur Miller, letter to "Joe," December 23, 1940; "New Orleans," first draft, Folder: New Orleans, Box: 1/5, RRPMC.

45 "Panama Canal," script, June 22, 1941; “Story of Immigrants," script, July 13, 1941, Folder: "Hidden History," Box: 2/5, RRMPC.

${ }^{46}$ Harrell, "The Library of Congress Radio Research Project," 449.

${ }^{47}$ Cohen and Harrell, "Draft of Prospectus," Folder: Radio Research Project "Hidden History" Ideas, Box: Radio Research Project, "Hidden History" and "Americans Talk Back," RRPMC.

48 "Panama Canal," script, 1, Folder: "Hidden History," Box: 2/ 5 RRPMC.

${ }^{49}$ Hilmes, Network Nations, 130.

50 "Content of the Second Series Hidden History," 6, Folder: Radio Research

Project, "Hidden History" Overview, Box: Radio Research Project, "Hidden History" and "Americans Talk Back," RRPMC.

${ }^{51}$ Robert Baron, “'All Power to the Periphery': The Public Folklore Thought of Alan Lomax," Journal of Folklore Research 49, no. 3 (2012): 277, 279.

${ }^{52}$ Rosemary Levy Zumwalt, American Folklore Scholarship: A Dialogue of Dissent (Bloomington: Indiana University Press, 1988), 5-7.

${ }^{53}$ Simon Bronner, Following Tradition: Folklore in the Discourse of American Culture (Logan: Utah State University Press, 1998), 75.

${ }^{54}$ Regina Bendix, In Search of Authenticity: The Formation of Folklore Studies (Madison: University of Wisconsin Press, 1997), 129-131; Zumwalt, American Folklore Scholarship, 5-7, 10. 
${ }^{55}$ D. K. Wilgus, Anglo-American Folksong Scholarship since 1898 (New Brunswick: Rutgers University Press, 1959), 157.

${ }^{56}$ For further information on popular interest in folklore see Rachel Donaldson, "I Hear America Singing": Folk. Music and National Identity (Philadelphia: Temple University Press, 2014); David E. Whisnant, All That Is Native and Fine (Chapel Hill: University of North Carolina Press, 1983); Daniel J. Walkowitz, City Folk: English Country Dance and the Politics of Folk in Modern America (New York: New York University Press, 2010); Nolan Porterfield, Last Cavalier: The Life and Times of John A. Lomax, 1867-1948 (Urbana: University of Illinois Press, 1996); Ronald D. Cohen, A History of Folk Music Festivals in the United States (Lanham: Scarecrow Press, 2008).

${ }^{57}$ Filene, Romancing the Folk, 137; Alan Jabbour, "Forward" in Transforming Tradition: Folk Music Revivals Examined, ed. Neil V. Rosenberg (Urbana: University of Illinois Press, 1993), 7, 13.

${ }^{58}$ While John Lomax maintained fairly conservative social and political views, this was not the case with Alan. When collecting folk music in the 1930s, Alan saw little difference between the "Southern system of Black oppression" and fascism. Folk music provided a means for the oppressed Black working-class to safely protest their conditions and unite together in shared experiences. See Baron, "The Public Thought of Alan Lomax," 295. Other leftist folklore collectors viewed black folk music, especially blues music, in a similar way. The Communist organizer Lawrence Gellert, for instance, interpreted blues music as a cultural form of male proletarian protest. See Steven Garabedian, "Reds, Whites, and the Blues: Lawrence Gellert, 'Negro Songs of Protest,' and the Left-Wing Folk-Song Revival of the 1930s and 1940s," American Quarterly 57, no. 1 (March 2005): 182, 192, 196-198.

59 “General Statement of Plan to Script Writers Working on Regional Documentary Programs," 1, Folder: Untitled, Box: 3/5, RRPMC.

${ }^{60}$ Alan Lomax, "Part III: Documentary Activities," in Report of the Radio Research Project, The Library of Congress (January 1941-February 1942), RRPMC. Michele Hilmes argues that recording activities at the $\mathrm{BBC}$ served as a precursor to the RRP's sound truck experiment. Prior to the war, the BBC employed the Mobile Recording Unit to bring people's voices to the British listening public. Producer Olive Shapely used it to record people in their homes, on the street, and at work. These interviews took on a political dimension when she focused on workers and the unemployed, women, and other voices often omitted from mainstream media. This approach, according to Hilmes, deeply affected the radio projects that Archibald MacLeish would oversee at the Library of Congress. See Hilmes, Network Nations, 123.

${ }^{61}$ Harrell, "The Library of Congress Radio Research Project," 449. 
62 "The Ballad Hunter" script, Library of Congress Radio Research Project Report, 1942 Miscellaneous, RRPMC.

${ }^{63}$ Benjamin Botkin, "Folklore as a Neglected Source of Social History," in The Cultural Approach to History, ed. Caroline F. Ware (New York: Columbia University Press, 1940), 308, 312. Carl Becker's 1931 AHA presidential address is often viewed as a call for historians to connect more with the general public: "Our proper function is not to repeat the past but to make use of it, to correct and rationalize for common use Mr. Everyman's mythological adaptation of what actually happened." See Carl Becker, "Everyman His Own Historian,” December 29, 1931, American Historical Association, accessed January 2, 2018, https:/ / www.historians.org/about-aha-and-membership/aha-history-andarchives/presidential-addresses/carl-l-becker.

64 "Outline of Proposed Defense Activities for the Radio Research Project," 1, Folder: Radio Research Project, General, Box: Radio Research Project, "Hidden History" and "Americans Talk Back," RRPMC.

65 “Looking for a Home," 2, Folder: Okie, Box: 3/5, RRPMC.

66 "America in the Summer (1941)," 1-2, Folder: America in the Summer (1941) transcript, Box: 3/5, RRPMC; Hilmes, Network Nations, 131.

67 "Report to the Nation: 'Library of Congress_-Radio Research"' (October 7, 1941), 23, RRPMC.

${ }^{68}$ Cohen, letter to Archibald MacLeish (January 24, 1942), Report of the Radio Research Project, The Library of Congress, 1, RRPMC.

${ }^{69}$ Alan Lomax Interview, Folder: Asheville, Box: 3/5, RRPMC.

${ }^{70}$ Alan Lomax telegrams, Folder: Declaration of War, Box: 1/5, RRPMC.

${ }^{71}$ Interview A6, Folder: "Declaration of War," Box: 1/5, RRPMC.

72 “Dear Mr. President," script, 8, Folder: “Dear Mr. President” (1/3), Box: 1/5, RRPMC.

${ }^{73}$ David Helfeld, interviewed by Charles Todd and Robert Sonkin, New York, NY, 1942, Library of Congress, AFC 1942/003: AFS 6411, Side A, http://hdl.loc.gov/loc.afc/afc1942003.sr14.

${ }^{74}$ W.C. Curry, interviewed by Charles Johnson and Lewis Jones, Nashville, Tennessee, December 1941, Library of Congress, AFC 1941/004: AFS 6361, Side A, http://hdl.loc.gov/loc.afc/afc1941004.sr05.

${ }^{75}$ Reverend W. J. Faulkner, Fadie France, and Walter Hadley, interviewed by Charles Johnson and Lewis Jones, Nashville, Tennessee, December 1941, Library of Congress, AFS 6361, LWO 4872, Reel 407, Side A, http://hdl.loc.gov/loc.afc/afc1941004.sr05.

${ }^{76}$ Smith (no first name), Private in the US Army, interviewed by John Henry Falk, January or February 1942, AFC 1942/003: AFS 6431, Side A, 
http://hdl.loc.gov/loc.afc/afc1942003.sr31.

77 These interviews illustrate support for civil rights mobilization just prior to and during the war, including A. Philip Randolph's March on Washington Movement in the summer of 1941, and the Pittsburgh Courier's "Double V Campaign" against racism abroad and in the United States.

${ }^{78}$ Fletcher Collins, letter to Alan Lomax, December 18, 1941, Folder: "December 7th" and "Dear Mr. President," Box: 1/5, RRPMC.

${ }^{79}$ Savage, Broadcasting Freedom; Barbara Savage, "Radio and the Political Discourse of Racial Equality," in Radio Reader Essays in the Cultural History of Radio, ed. Michele Hilmes and Jason Loviglio (New York: Routledge, 2002), 243-255.

${ }^{80}$ Filene, Romancing the Folk, 153-154.

${ }^{81}$ James T. Sparrow, Warfare State: World War II Americans and the Age of Big Government (Oxford: Oxford University Press, 2011), 63.

${ }^{82}$ Questionnaire for "Americans Talk Back," Folder: Overview of "Americans Talk Back," Box: Radio Research Project, "Hidden History" and "Americans Talk Back"; Radio Research Project Response Sheets for "Americans Talk Back," Folder: Untitled, Box: 4/5, RRPMC.

${ }^{83}$ Letter to Mr. J. Triedman of Haverhill High School, Haverhill, Mass., Folder: Radio Research Project "HH” Correspondence, Box: 4/5, RRPMC.

${ }^{84}$ National Council on Public History, "About the Field," last modified June 9, 2012, http:/ / ncph.org/what-is-public-history/about-the-field/. 